Nordisk Tidsskrift for Kriminalvidenskab 2010

\title{
Understanding What Works: Lessons For the Nordic COUNTRIEs?
}

By DR. JAMES BontA ${ }^{1 *}$

Developed in the 1980s and first formalized in 1990, the Risk-NeedResponsivity (RNR) model has been used with increasing success to assess and rehabilitate criminals in Canada. As suggested by its name, it is based largely on three principles: 1) the risk principle asserts that criminal behaviour can be reliably predicted and that treatment should focus on the higher risk offenders; 2) the need principle highlights the importance of criminogenic needs in the design and delivery of treatment; and 3) the responsivity principle describes how treatment should be matched to the learning style of the individual. However, the principles are less familiar to many of the Nordic countries. This paper summarizes the role of the principles guiding the development of offender rehabilitation programs and ends with a description of an RNR-based training program for probation officers.

Canada has a population of 33 million people, about $25 \%$ higher than the Nordic countries combined. However, the incarceration rate is 117 per 100,000 substantially higher than the average rate of 71 in the Nordic countries. Although Canada responds to crime in a more punitive fashion than the Nordic countries, the country also has a long tradition of valuing offender rehabilitation. Over the past few decades Canadian researchers have developed the Risk-Need-Responsivity (RNR) model to guide the assessment and treatment of offenders. Although the model has been highly influential in Canada, the United States and parts of Europe (e.g., the United Kingdom) it has received less attention from the Scandinavian countries. The purpose of this article is to familiarize readers in the Nordic countries of the RNR model and the benefits of the model.

Originally formulated in 1990 (Andrews, Bonta \& Hoge, 1990), the number of principles have since grown to 17 (Andrews \& Bonta, 2010a, b; Bonta \& Andrews, 2007). However, the following three principles remain at the core:

1. Risk principle: Match the level of service to the offender's risk to re-offend.

Provide intensive services to higher risk clients and minimal services to lower risk clients.

2. Need principle: Assess criminogenic needs and target them in treatment.

\footnotetext{
The views expressed are those of the author and do not necessarily represent the views of Public Safety Canada.
} 
Criminogenic needs are the dynamic risk factors associated with criminal behaviour.

3. Responsivity principle: Maximize the offender's ability to learn from a rehabilitative intervention by providing cognitive behavioural treatment and tailoring the intervention to the learning style, motivation, abilities and strengths of the offender.

There are two parts to the responsivity principle: general and specific responsivity. General responsivity calls for the use of cognitive social learning methods to influence behaviour. Cognitive social learning strategies are the most effective regardless of the type of offender (i.e., female offender, psychopath, sex offender). Core correctional practices such as prosocial modeling, the appropriate use of reinforcement and disapproval, and problem solving (Dowden \& Andrews, 2004) spell out the specific skills represented in a cognitive social learning approach.

Specific responsivity is a "fine tuning" of the cognitive behavioural intervention. It takes into account strengths, learning style, personality, motivation, and bio-social (e.g., gender, race) characteristics of the individual.

Before summarizing the evidence in support of the RNR model with respect to treatment, we begin with a brief discussion of the role of offender risk assessment and its relationship to offender rehabilitation programs. I will try and show that good risk and need assessment is the foundation to effective programming. Following this I will present the treatment evidence and an illustration of applying the RNR principles to everyday correctional practice.

\section{RNR Model and Offender Risk Assessment}

The risk principle states that offender recidivism can be reduced if the level of treatment services provided to the offender is proportional to the offender's risk to re-offend. The principle has two parts to it: 1) level of treatment and, 2) offender's risk to re-offend. I will reserve our discussion of offender treatment for later but here I focus on the offender's risk to re-offend.

There is ample evidence that criminal behaviour can be predicted in a reliable manner with actuarial, evidence-based risk instruments. Some of these instruments are largely comprised of static risk factors that do not change (e.g., criminal history) whereas others have dynamic risk factors that are amenable to change (e.g., employment, substance abuse). The two types of instruments have been characterized as "second generation" risk scales (static) and "third generation" or dynamic risk scales (Bonta, 1996). The advantage of third generation risk instruments such as the Level of Service Inventory- Revised (LSI-R; Andrews \& Bonta, 1995) is that they follow the need principle because they sample the important dynamic risk factors. 
The need principle calls for the focus of correctional treatment to be on the dynamic risk factors or criminogenic needs. Criminogenic needs are directly linked to criminal behaviour. Offenders have many needs deserving of treatment but not all of these needs are associated with their criminal behaviour. These criminogenic needs are subsumed under the major predictors of criminal behaviour referred to as "central eight" risk/needs factors (Andrews \& Bonta, 2010a).

Table 1 presents an overview of the major risk/need factors along with some less promising targets for interventions (i.e., non-criminogenic needs) and suggestions for assessment and treatment. The seven major risk/need factors of the central eight are dynamic (criminal history completes the list but it is a static risk factor). These seven criminogenic needs are worth assessing and targeting in interventions. To further illustrate the distinction between the two types of needs let us examine procriminal attitudes which are labelled criminogenic. Shifting attitudes through treatment from the procriminal to the prosocial will lead to less criminal behaviour and more prosocial behaviour (what you think influences how you behave). However, increasing self-esteem without changes in procriminal attitudes runs the risk of resulting in confident criminals. Decreasing self-esteem may lead to miserable criminals. The probability of criminal behaviour may or may not change as a function of self-esteem.

Table 1. The seven major risk/need factors along with some minor risk/need factors

\begin{tabular}{|l|l|l|}
\hline \multicolumn{1}{|c|}{$\begin{array}{c}\text { Major risk/need } \\
\text { factor }\end{array}$} & \multicolumn{1}{|c|}{ Indicators } & \multicolumn{1}{|c|}{ Intervention goals } \\
\hline $\begin{array}{l}\text { Antisocial personality } \\
\text { pattern }\end{array}$ & $\begin{array}{l}\text { Impulsive, adventurous } \\
\text { pleasure seeking, } \\
\text { restlessly aggressive, } \\
\text { irritable }\end{array}$ & $\begin{array}{l}\text { Build self-management } \\
\text { skills, teach anger } \\
\text { management }\end{array}$ \\
\hline Procriminal attitudes & $\begin{array}{l}\text { Rationalizations } \\
\text { for crime, negative } \\
\text { attitudes to the law }\end{array}$ & $\begin{array}{l}\text { Counter rationalizations } \\
\text { with prosocial attitudes; } \\
\text { build up a prosocial } \\
\text { identity }\end{array}$ \\
\hline $\begin{array}{l}\text { Social supports for } \\
\text { crime }\end{array}$ & $\begin{array}{l}\text { Criminal friends, } \\
\text { isolation from prosocial } \\
\text { others }\end{array}$ & $\begin{array}{l}\text { Replace procriminal } \\
\text { friends and associates } \\
\text { with prosocial friends } \\
\text { and associates }\end{array}$ \\
\hline
\end{tabular}




\begin{tabular}{|c|c|c|}
\hline Substance abuse & $\begin{array}{l}\text { Abuse of alcohol and/ } \\
\text { or drugs }\end{array}$ & $\begin{array}{l}\text { Reduce substance abuse, } \\
\text { enhance alternatives to } \\
\text { substance use }\end{array}$ \\
\hline $\begin{array}{l}\text { Family/marital } \\
\text { relationships }\end{array}$ & $\begin{array}{l}\text { Poor parental } \\
\text { monitoring and } \\
\text { disciplining, poor } \\
\text { family relationships }\end{array}$ & $\begin{array}{l}\text { Teaching parenting } \\
\text { skills, enhance warmth } \\
\text { and caring }\end{array}$ \\
\hline School/work & $\begin{array}{l}\text { Poor performance, low } \\
\text { levels of satisfactions }\end{array}$ & $\begin{array}{l}\text { Enhance work/ } \\
\text { study skills, nurture } \\
\text { interpersonal } \\
\text { relationships within the } \\
\text { context of work and } \\
\text { school }\end{array}$ \\
\hline $\begin{array}{l}\text { Prosocial recreational } \\
\text { activities }\end{array}$ & $\begin{array}{l}\text { Lack of involvement in } \\
\text { prosocial recreational/ } \\
\text { leisure activities }\end{array}$ & $\begin{array}{l}\text { Encourage participation } \\
\text { in prosocial recreational } \\
\text { activities, teach } \\
\text { prosocial hobbies and } \\
\text { sports }\end{array}$ \\
\hline $\begin{array}{l}\text { Non-criminogenic, } \\
\text { minor needs }\end{array}$ & Indicators & \\
\hline Self-esteem & $\begin{array}{l}\text { Poor feelings of self- } \\
\text { esteem, self-worth }\end{array}$ & \\
\hline $\begin{array}{l}\text { Feelings of personal } \\
\text { distress }\end{array}$ & Anxious, sad & \\
\hline Major mental disorder & $\begin{array}{l}\text { Schizophrenia, manic- } \\
\text { depression }\end{array}$ & \\
\hline Physical health & $\begin{array}{l}\text { Physical deformity, } \\
\text { nutrient deficiency }\end{array}$ & \\
\hline
\end{tabular}

\section{The RNR Model and Offender rehabilitation}

Evidence that some interventions can reduce recidivism has existed for over half a century (Kirby, 1954) and throughout the 1950s and 1960s, rehabilitation was seen as a promising approach to reducing recidivism. Then in the 1970 s, the view changed with the publication of a review of offender rehabilitation programs by 
Robert Martinson and his colleagues (Lipton, Martinson \& Wilks, 1975; Martinson, 1974). They found that approximately 50 to $60 \%$ of studies supported the effectiveness of treatment but concluded that "nothing works". The "nothing works" movement seized criminal justice, particularly in the United States. If offenders could not be rehabilitated then what was society to do with the problem of crime. Many answered that punishment or deterrence could reduce criminal behaviour. Thus began the "get tough" movement. However, after 30 years of experimentation with getting tough not only have prison and probation populations skyrocketed but the weight of the evidence is that deterrence has had hardly any impact on offender recidivism and in some situations, actually increased recidivism (see chapter 13 of Andrews \& Bonta, 2010a; Pratt \& Cullen, 2005; Smith, Goggin \& Gendreau, 2002; Villettaz, Killias, \& Zoder, 2006).

The one good thing that came out of the "nothing works" ideology was that researchers became more rigorous in their evaluations of treatment and some researchers developed a theoretical model to explain why some interventions were effective and others were not (e.g., Andrews, Zinger, Hoge, Bonta, Gendreau \& Cullen, 1990).

Recall that the risk principle has two components. The first part emphasizes the importance of reliably predicting criminal behaviour and thus, the need for evidence-based risk instruments. The second component highlights the need to properly match the level of service to the offender's risk level. That is, as risk level increases then the amount of treatment needed to reduce recidivism also increases. To the reader, this may appear to be common sense - higher risk offenders have more criminogenic needs than lower risk offenders and therefore more intervention is needed to address these needs. However, in everyday practice there is a tremendous pressure to focus resources on lower risk offenders. After all, low risk offenders are more cooperative and motivated to comply with treatment demands than high risk offenders.

Inappropriate matching of treatment intensity with offender risk level can lead to wasted treatment resources. Treatment provided for low risk offenders is associated with only an average 3\% reduction in recidivism and there have been some instances where treatment for low risk offenders actually increased recidivism (Bonta, Wallace-Capretta \& Rooney, 2000). It is when treatment services are provided to high risk offenders that we find significantly lower recidivism compared to treatment provided to low risk offenders. In fact, in 374 tests of the risk principle, treatment delivered to high risk offenders was associated with an average $10 \%$ difference in recidivism (Andrews \& Dowden, 2006).

Can we achieve reductions in recidivism beyond $10 \%$ ? What happens when we include the need and responsivity principles? The risk principle speaks of who 
should be treated (the higher risk offender), the need principle speaks to what should be treated (criminogenic needs) and the responsivity principle helps determine how to treat.

Based on tests of the need principle, successfully addressing criminogenic needs is associated with an average $19 \%$ difference in recidivism. Treatments that focus on non-criminogenic needs are associated with a slight increase in recidivism (about 4\%; p. 367 of Andrews \& Bonta, 2010a). If we examine only adherence to the general responsivity principle (i.e., use cognitive behavioural methods of intervention) we find on average, a $23 \%$ difference in recidivism (Andrews \& Bonta, 2010a). Finally, when offender treatment programs put all three principles into action then the effectiveness of correctional treatment can be quite significant. Figure 1 shows the accumulating effectiveness of treatment when there is increased adherence to the RNR principles.

Figure 1. Adherence to the RNR principles by setting

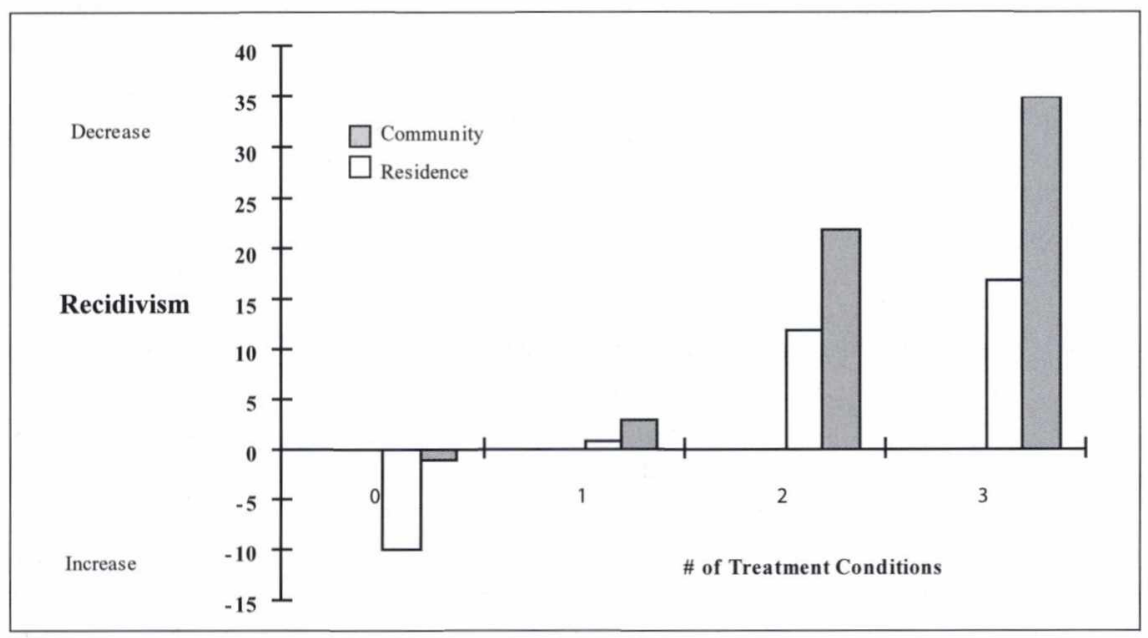

(Adapted from Andrews \& Bonta, 2010a)

Treatment interventions that do not adhere to any of the three principles (that is, they target the non-criminogenic needs of low risk offenders using non-cognitivebehavioural techniques) are actually criminogenic! This situation is particularly exacerbated when the treatment is given in residential/custodial settings (we presume because the offender cannot escape from the well-intentioned but poorly designed treatment). However, if a treatment intervention begins to adhere to one of 
the principles we start to see reductions in recidivism and when all three principles are evident in a rehabilitation program then we see average recidivism differences between the treated and non-treated offenders of 17 percentage points when delivered in residential/custodial settings and 35 percentage points when delivered in community settings. Treatment can work in residential and custodial settings but effectiveness is maximized when the treatment is in a community setting.

\section{Translating the RNR Principles to the Real World}

The greatest challenge is transferring the RNR model into "real world" settings. It is one thing for scientists to demonstrate that a treatment program can work but it is a very different matter to make it work in correctional agencies with a diverse work force in terms of education, values and experience, conflicting criminal justice policies and management practices that are not conducive to selecting and training of staff in effective assessment techniques. We know that when treatment programs that have demonstrated reduced recidivism in tightly controlled experiments are adopted by correctional agencies that their effectiveness is significantly diminished (Lipsey, 1999). Andrews and Bonta (2010a, Chapter 12) reported that the effectiveness of treatment delivered in the real world is about half of the effect of the experimental, demonstration program. Despite this sobering finding we are also learning what is necessary to enhance the delivery of effective treatment services.

Given the research to date, to provide the best assessments and interventions correctional agencies need to:

a) embrace a general vision that it is in the best interest for all to provide cognitive behavioural services to offenders

b) select, properly train, and supervise staff in the use of RNR assessments and the delivery of services that adhere to RNR

c) provide policies and organizational supports for the RNR model

Agencies that that are able to achieve this level of commitment show significant reductions in recidivism compared to agencies that fail to adhere to the risk-need-responsivity principles (Andrews \& Dowden, 2005; Lowenkamp, 2004; Lowenkamp, Latessa \& Smith, 2006). Obviously, there is still much work to do but the RNR gives us a roadmap of what must be done.

\section{The Strategic Training Initiative in Community Supervision (STICS)}

In Canada, there are over 95,000 offenders under community supervision (Public Safety Canada, 2009) while there are over five million in the United States (Glaze \& Bonczar, 2007). Despite its prevalence, very little is actually known about the effectiveness of community supervision. In a review of 15 studies on the 
effectiveness of community supervision, Bonta and his colleagues (Bonta, Rugge, Scott, Bourgon \& Yessine, 2008) found an average decrease in recidivism of approximately two percentage points for offenders under community supervision. With respect to violent recidivism, there was no decrease in recidivism associated with community supervision. These findings led us to question why community supervision is not more effective given the large literature on the effectiveness of offender rehabilitation programming.

In an attempt to understand why community supervision is less effective than commonly thought, Bonta et al. (2008) looked inside "the black box of supervision". Sixty-two probation officers were asked to audiotape their supervision sessions with clients. An analysis of 154 audiotapes (some officers submitted more than one) found relatively poor adherence to the RNR principles. For example, other than substance abuse and family/marital problems, most criminogenic needs were infrequently addressed. Procriminal attitudes were discussed in only $3 \%$ of cases. Furthermore, cognitive-behavioural techniques such as prosocial modeling and role playing along with practice were demonstrated in less than one-quarter of the sessions. These findings opened the door to training in better adherence to the RNR principles in one-on-one supervision.

Incorporating advances in correctional research, a training program was developed called the Strategic Training Initiative in Community Supervision (STICS). The STICS training consisted of two main components: the three day training and ongoing skill maintenance. The three day training was based on 10 modules, which were designed to accomplish the following: explain the overview and rationale for STICS; emphasize the RNR principles and how to implement them into practice; highlight the importance of targeting attitudes, building rapport, using prosocial modeling, reinforcement and cognitive-behavioural techniques to influence change; and outline the benefits of using a strategic supervision structure in each individual session as well as over the entire supervision period. The ongoing skill maintenance component consisted of monthly meetings where officers could discuss and practice their skills, formal clinical feedback on officer-client sessions, and a refresher course which took place approximately one year after the initial training.

This training protocol was guided by the RNR model in the following ways. First, the probation officers who volunteered for the project were asked to recruit medium and high risk clients (risk principle). Second, there were training modules attentive to the identification of criminogenic needs, with an emphasis on changing procriminal attitudes (need principle). Finally, probation officers were trained in various intervention techniques ranging from rapport building to cognitive restructuring (responsivity principle). The major method for measuring the proba- 
tion officers' use of the skills taught was via audiotapes of supervision sessions. Finally, the training program was evaluated experimentally.

Eighty probation officers were randomly assigned using a 60:40 ratio to either training or to a control group. We over-sampled the experimental cases in order to have sufficient power for planned analyses specific to the trained officers. Subsequently, 51 probation officers attended the STICS training while 29 officers were assigned to the control group. Even though the probation officers were all volunteers, 28 officers did not submit any post-training data. The attrition rate for the experimental and control groups was not significantly different $(35.3 \%$ for the experimental group and $34.5 \%$ for the control group; $\left.\chi^{2}(80,1)=0.005 ; p=.94\right)$. The reasons for attrition were benign in $35.7 \%$ of the cases (e.g., job change, maternity leave, or extended leave) and for the remaining $64.3 \%$ of cases, data was not provided for various reasons (e.g., not enough time, too much work, clients refused to volunteer). No statistically significant differences between the two groups on the reasons for attrition or personal demographic characteristics were found.

In total, the 52 participating probation officers recruited 143 clients. One hundred clients were supervised by 33 STICS officers and 43 clients were supervised by 19 control group officers. The probation officers submitted 295 post-training audiotapes. There were 220 STICS sessions (98 Tape 1 or the beginning of supervision, 71 Tape 2 at three months, and 51 Tape 3 at six months) and 75 control sessions (42 Tape 1, 22 Tape 2, and 11 Tape 3). On average, the STICS officers submitted significantly $(\mathrm{t}(50)=2.43 ; \mathrm{p}=.02)$ more audiotapes $(\mathrm{M}=6.76 ; \mathrm{SD}=$ $4.35)$ than did the control officers $(M=4.00 ; \mathrm{SD}=3.09)$.

The coding of the audiotapes focused on two general areas: 1) the content of discussions (e.g., discussing criminogenic needs, the conditions of probation) and 2) the quality and use of techniques of influence (e.g., using cognitive-behavioral techniques, prosocial modeling). Audiotapes were coded in 5-minute segments by a team of two trained coders. In order for a variable to be coded as present, there had to have been at least two examples to support the coding within the five minute segment (e.g., a casual reference to a criminogenic need would not be scored). Upon completion of the coding of the 5-minute segments, the coders would listen to the tape in its entirety and rate the session on measures of general quality (with respect to RNR). The 5-minute segments and the tape in its entirety were coded independently by the two coders and then they reached a consensus coding that served as the basis for analysis.

\section{Results}

The average length of a session was approximately 26 minutes $(\mathrm{SD}=11)$ with no significant difference between the STICS and control groups. An analysis of 
the content of the discussions found that the STICS group devoted a greater proportion more of their sessions to discussing procriminal attitudes, both when it was identified as a criminogenic need for that client and also when it was not identified (see Table 2). This was to be expected given that the STICS training focused on procriminal attitudes and how to replace them with prosocial attitudes. Additionally, the STICS sessions had a significantly $(\mathrm{t}(293)=4.22 ; \mathrm{p}=.000)$ higher proportion of their sessions spent discussing criminogenic needs $(\mathrm{M}=0.62$; $\mathrm{SD}=0.28)$ with fewer discussions $(0.31)$ on noncriminogenic needs. In contrast, officer-client discussions during supervision sessions of the control group were contrary to the need principle. In other words, more of the session was devoted to noncriminogenic needs.

Table 2. The Content of Discussions

\begin{tabular}{|l|c|c|}
\hline \multirow{2}{*}{ Discussion Area } & \multicolumn{2}{|c|}{ Proportion of Session } \\
\cline { 2 - 3 } & STICS & Control \\
\hline & M (SD) & M (SD) \\
\hline Probation conditions & $.12(.16)$ & $.24(.27)^{* * *}$ \\
\hline Noncriminogenic & $.31(.26)$ & $.43(.31)^{* *}$ \\
\hline Attitudes - All sessions & $.13(.198)$ & $.02(.10)^{* * *}$ \\
\hline $\begin{array}{l}\text { Attitudes - When identified as } \\
\text { problem }\end{array}$ & $.16(.23)$ & $.06(.15)^{*}$ \\
\hline Any Criminogenic & $.61(.28)$ & $.45(.31)^{* * *}$ \\
\hline
\end{tabular}

$* \mathrm{p}<.05 ; * * \mathrm{p}<.01 ; * * * \mathrm{p}<.001$.

With respect to the officer's skills and intervention techniques, significant betweengroup differences were found on four of the five constructs measured (Table 3). Officers in the STICS group demonstrated significantly higher quality scores on Structuring Skills, Relationship Building Skills, Cognitive Techniques, as well as the global Effective Correctional Skills. Although the STICS officers demonstrated higher quality scores on Behavioural Techniques $(M=10.23)$ than the control officers $(M=8.67)$, this difference was not statistically significant $(\mathrm{t}(50)=1.89$; $\mathrm{p}=.06)$. 
Table 3. Assessment of Probation Officer Skill Levels at Post-training

\begin{tabular}{|l|c|c|}
\hline Skill & STICS $(\mathbf{N}=\mathbf{3 3})$ & Control (N = 19) \\
\hline & M (SD) & M (SD) \\
\hline Structuring Session & $13.07(5.59)^{* *}$ & $8.92(3.69)$ \\
\hline Relationship Skills & $13.61(2.64)^{* *}$ & $11.56(2.21)$ \\
\hline Behavioural Techniques & $10.23(3.02)$ & $8.67(2.54)$ \\
\hline Cognitive Techniques & $1.58(2.21)^{* *}$ & $0.01(0.03)$ \\
\hline Effective Correctional Skills & $38.49(11.38)^{* *}$ & $29.16(7.27)$ \\
\hline
\end{tabular}

$* *$ indicates a significant difference at $\mathrm{p}<.01$.

One of the primary training elements was to enhance the cognitive intervention techniques of probation officers so they may more effectively target procriminal attitudes and cognitions. Given its importance, we examined how many officers had at least one discussion on attitudes with any of their clients as well as how many officers employed Cognitive Techniques at least once in all of the audiotapes they submitted. There were significantly $\left(\chi^{2}(1, \mathrm{~N}=52)=20.55 ; \mathrm{p}=.001\right)$ more STICS officers (75.8\% of 33 officers) who had at least one discussion with their clients on attitudes than control officers ( $10.5 \%$ of 19 officers). In fact, $69.7 \%$ of the STICS officers employed Cognitive Techniques at least once in all of the audiotapes they submitted, significantly more than the $5.3 \%$ of 19 control officers $\left(\chi^{2}\right.$ $(1, \mathrm{~N}=52)=20.14 ; \mathrm{p}=.000)$.

\section{Recidivism}

Recidivism was defined as a new conviction as recorded in Canada's national police database. At post-training, 2-year recidivism differences emerged for the clients of the STICS probation officers and the control clients. For the probationers in the STICS group $(\mathrm{N}=75)$ the recidivism rate was $25.3 \%(95 \%$ Confidence Interval $=15.5$ to 35.1$)$ and for the control clients $(\mathrm{N}=37)$ the rate was $40.5 \%$ $(95 \%$ Confidence Interval $=24.7$ to 56.3$)$.

\section{RNR in the Real World and Implications from STICS}

The RNR principles have been applied in the development of group-based intervention programs but, they have not been systematically used in the one-on-one supervision of offenders. In the STICS study, the key RNR principles were incorporated into community supervision. It is the medium and high risk offenders who are best served by the initiative, where probation officers are taught cognitive-be- 
havioural skills to address the procriminal and dysfunctional attitudes that underlie other criminogenic needs. In the evaluation, probation officers were randomly assigned to either three days of training in the STICS model or to a control condition of services as usual. The probation officers were asked to audiotape some of their sessions with clients and the audiotapes were coded with respect to adherence to the need and responsivity principles. The evaluation asked two questions: 1) did training change the behaviour of the probation officers, and 2) was there a difference in the future criminal behaviour of the clients of the these officers?

Based on an analysis of the audio taped supervision sessions officers trained in the STICS model showed increased adherence to the need principle. The trained officers spent proportionately more of their supervision sessions (.61) discussing the criminogenic needs of their clients compared to the control officers (.45). In addition, the training's focus on procriminal attitudes appeared to have a significant impact on the behaviour of the STICS probation officers. Across all of the sessions, discussions of procriminal attitudes were far more likely to occur among the STICS officers than the control group. The findings with respect to procriminal attitudes can be compared to those reported for the Manitoba probation officers by Bonta et al. (2008). In that study, attitudes when identified as problematic were discussed rarely. In the present study, for the experimental probation officers, discussions of procriminal attitudes occurred in nearly half of the sessions $(45.2 \%)$.

Also noteworthy was the differential attention paid to noncriminogenic needs and the conditions of probation. The control group spent a larger proportion of their sessions discussing noncriminogenic needs and the conditions of probation than the experimental group. Given the general treatment literature and the RNR principles, such attention is counter-productive (Andrews, Zinger et al., 1990; Andrews \& Bonta, 2010a, b). Although probation officers have a duty to enforce the conditions of the court and to deal with crisis and issues of a noncriminogenic nature, their time needs to be balanced with addressing the factors that are more directly related to criminal behaviour. Spending nearly half of their time on the noncriminogenic needs of their clients, as the control officers demonstrated, leaves little time to deal with a probationer's criminogenic needs.

The use of cognitive techniques, without specific training, was rare. Only one probation officer in the control group evidenced the use of a cognitive technique. Among the probation officers who attended training, 23 officers $(69.7 \%)$ used cognitive techniques. According to the responsivity principle, cognitive-behavioural interventions are associated with recidivism reductions and should be encouraged. However, probation officers require specific training on these skills as they do not occur naturally.

It is one thing to demonstrate that training can change the behaviour of the 
probation officers but it is important to also show that the trained officers may have an influence on the criminal behaviour of their clients. We found betweengroup differences in the 2-year reconviction rate with a $15 \%$ difference favouring the clients of the trained officers. However, perhaps because of the limited sample size, the Confidence Intervals did overlap. Nevertheless, the lower recidivism rate for the clients of probation officers trained in the STICS model is promising and mirrors the findings from the general treatment "real world" literature. A metaanalysis of 11 studies that adhered to the RNR principles and that were conducted under everyday conditions found an average effect size of $r=.15$ which translates into a $15 \%$ reduction in recidivism (Andrews \& Bonta, 2010a).

Training probation officers to better adhere to the RNR principles is feasible and has positive benefits. The STICS training demonstrated a change in both the behaviour of the officers and their clients. Considering the fact that the average length of a session was only 26 minutes, it was striking that a reduction in offender recidivism was observed. Nevertheless, caution in generalizing the results from this study is advised. The sample size was relatively small and attenuated the power of some of the statistical analyses and the probation officers in the study were volunteers. It is unknown how effective the STICS model would be if introduced to staff who are perhaps more resistant to the model. However, it is our belief that the appropriate organizational and management support for STICS training would circumvent staff resistance.

Taken as a whole, the STICS training is the first experimental evaluation of a training program that follows the RNR principles. Staff practices that are considered to be important have been suggested by reviews of the literature (Dowden \& Andrews, 2004) and elements of such "core correctional practice" have been evaluated in probation officer training (Trotter, 1996). Until now, there has not been a comprehensive RNR training program. For those community probation officers and correctional agencies interested in "what works", the results of the present study provide promise and await replication.

\section{References}

Andrews, D. A., \& Bonta, J. (1995). The Level of Service Inventory - Revised. Toronto: Multi-Health Systems.

Andrews, D. A., \& Bonta, J. (2010a). The psychology of criminal conduct ( $5^{\text {th }}$ ed.). New Providence, NJ: LexisNexis Matthew Bender.

Andrews, D. A., \& Bonta, J. (2010b). Rehabilitating criminal justice policy and practice. Psychology, Public Policy and Law, 16, 39-55.

Andrews, D. A., Bonta, J., \& Hoge, R .D. (1990). Classification for effective rehabilitation: Rediscovering psychology. Criminal Justice and Behavior, 17, 
19-52.

Andrews, D. A., \& Dowden, C. (2005). Managing correctional treatment for reduced recidivism: A meta-analytic review of program integrity. Legal and Criminological Psychology, 10, 173-187.

Andrews, D. A., \& Dowden, C. (2006). Risk principle of case classification in correctional treatment: A meta-analytic investigation. International Journal of Offender Therapy and Comparative Criminology, 50, 88-100.

Andrews, D. A., Zinger, I., Hoge, R. D., Bonta, J., Gendreau, P., \& Cullen, F. T. (1990). Does correctional treatment work?: A clinically relevant and psychologically informed meta-analysis. Criminology, 28, 369-404.

Bonta, J. (1996). Risk-needs assessment and treatment. In A. T. Harland (Ed.), Choosing correctional options that work: Defining the demand and evaluating the supply (pp. 18-32). Thousand Oaks, CA: Sage.

Bonta, J., \& Andrews, D. A. (2007). Risk-need-responsivity model for offender assessment and rehabilitation (User Report 2007-06). Ottawa: Public Safety Canada.

Bonta, J., Rugge, T., Scott, T., Bourgon, G., \& Yessine, A. (2008). Exploring the black box of community supervision. Journal of Offender Rehabilitation, 47, 248-270.

Bonta, J., Wallace-Capretta, S. \& Rooney, R. (2000). A quasi-experimental evaluation of an intensive rehabilitation supervision program. Criminal Justice and Behavior, 27, 312-329.

Dowden, C. \& Andrews, D. A. (2004). The importance of staff practice in delivering effective correctional treatment: A meta-analytic review of core correctional practice. International Journal of Offender Therapy and Comparative Criminology, 48, 203-214.

Glaze, L. E., \& T. P. Bonczar, T. P. (2007). Probation and Parole in the United States, 2006. Bureau of Justice Statistics Bulletin. Office of Justice Programs, U. S. Department of Justice.

Kirby, B. C. (1954). Measuring effects of treatment of criminals and delinquents. Sociology and Social Research, 38, 368-374.

Lipsey, M. W. (1999). Can rehabilitative programs reduce the recidivism of juvenile offenders? An inquiry into the effectiveness of practical programs. Virginia Journal of Social Policy and the Law, 6, 611-641.

Lipton, D., R. Martinson \& J. Wilks (1975). The effectiveness of correctional treatment: A survey of treatment evaluation studies. New York: Praeger.

Lowenkamp, C. T. (2004). Correctional program integrity and treatment effectiveness: A multi-site, program-level analysis. Unpublished doctoral dissertation, University of Cincinnati: Doctoral Dissertation. 
Lowenkamp, C. T., Latessa, E. J., \& Smith, P. (2006). Does correctional program quality really matter? The impact of adhering to the principles of effective intervention. Criminology \& Public Policy, 5, 575-594.

Martinson, R. (1974). What works? - questions and answers about prison reform. The Public Interest, 35, 22-54.

Pratt, T. C., \& Cullen, F. T. (2005). Assessing macro-level predictors and theories of crime: A meta-analysis. In M. Tonry (Ed.), Crime and justice: A review of research. (Vol. 32), pp. 373-450. Chicago, IL: University of Chicago Press.

Public Safety Canada (2009). Corrections and Conditional Release Statistical Overview: Annual Report 2009. Ottawa: Public Safety Canada.

Smith, P., Goggin, C., \& Gendreau, P. (2002). The effects of prison sentences and intermediate sanctions on recidivism: General effects and individual differences. (User Report 2002-01). Ottawa: Public Safety Canada.

Trotter, C. (1996). The impact of different supervision practices in community corrections. Australian and New Zealand Journal of Criminology, 29, 1-18.

Villettaz, P., Killias, M., \& Zoder, I. (2006). The effects of custodial vs. non-custodial sentences on re-offending: A systematic review of the state of the knowledge. Report to the Swiss National Science Foundation and the Campbell Collaboration Crime and Justice Group. Institute of Criminology and Criminal Law, University of Lausanne: Lausanne, Switzerland.

Address:

Corrections Research, Public Safety Canada

340 Laurier Avenue West, Ottawa, Ontario

Canada, K1A 0P8;

email: Jim.Bonta@ps.gc.ca. 